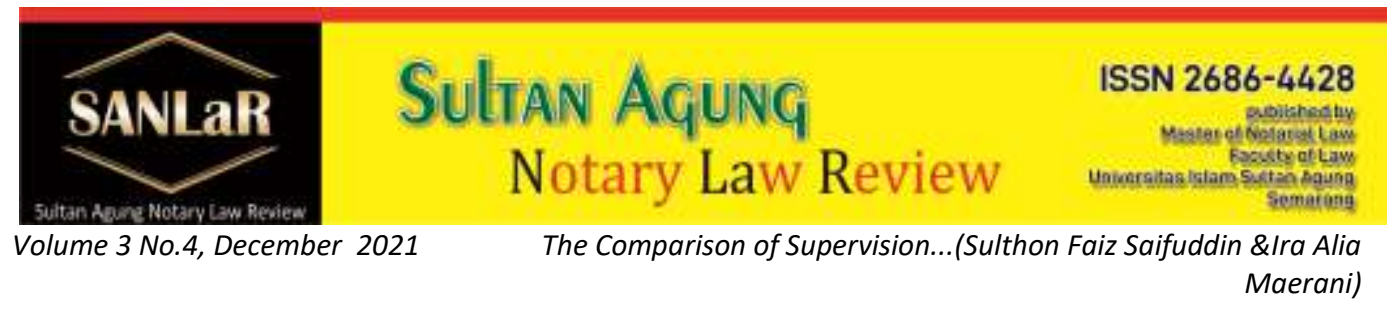

\title{
The Comparison of Supervision of Notaries and Land Deed Making Officials
}

\author{
Sulthon Faiz Saifuddin ${ }^{*}$ and Ira Alia Maerani* ${ }^{* *}$ \\ *) Faculty of Law, Universitas Islam Sultan Agung (UNISSULA) Semarang, E-mail: \\ sulthonfaiz8989@gmail.com \\ ${ }^{* *)}$ Faculty of Law, Universitas Islam Sultan Agung (UNISSULA) Semarang, E-mail: \\ ira.alia@unissula.ac.id
}

\begin{abstract}
Notaries and Land Deed Making Officials are public officials who are given the task, obligation and authority to make authentic deeds and are usually held by one person. Supervision of notaries and Land Deed Making Officials is a must because mistakes or omissions often occur during carrying out their positions. The author in this study tries to compare the supervision carried out on the notary and the Land Deed Making Officer with the aim of knowing the advantages and disadvantages of each supervisor based on the theory of supervision. This research is a normative juridical research by examining secondary data which is analyzed deductively. There are two legal theories used in this research, namely the theory of state power and the theory of supervision. The results showed that the supervision of the notary was carried out by two supervisory institutions, namely the Supervisory Council and the Honorary Council, while the supervision of the Land Deed Making Officer was carried out by two institutions, namely, the Supervisory Council and the Supervisor of the Land Deed Making Officer and the Association Honorary Council. Comparison of supervision between supervisory institutions is focused on four things, namely the form of supervision, type of supervision, supervisory mechanism and authority \& scope of supervision. Based on these four things, the Supervisory Board is the best supervisory agency, while the other three supervisory institutions need to be improved through changes or additions to their legal rules.
\end{abstract}

Keywords: Deed; Land; Maker; Notary; Official; Public; Supervision.

\section{Introduction}

The constitution affirms that the state of Indonesia is a state of law (rechtsstaat), not a state of power (machtsstaat). The rule of law in the sense that there is recognition of the principle of the rule of law and the constitution, adheres to 
the principle of separation and limitation of power according to the constitutional system regulated in the Constitution and guarantees justice for everyone, including against abuse of authority by those in power. ${ }^{1}$

Sudikno Mertokusumo argues that the main purpose of law is to create an orderly society, to create order and balance so that it is hoped that human interests will be protected. In order to achieve its objectives, the law is tasked with dividing rights and obligations between individuals in society, dividing authority and regulating the way in which legal problems are resolved and maintaining legal certainty. ${ }^{2}$

The realization of order, legal protection and especially legal certainty requires evidence that can explain a person's rights and obligations as a legal subject. These rights and obligations must be regulated and limited by documents whose validity is guaranteed to avoid overlapping.

Along with the development of legal knowledge and the need for law in society, more and more forms of agreements are made. ${ }^{3}$ The public as one of the legal subjects needs a notary as a figure whose information can be trusted and relied upon, and the signature and seal or stamp provide certainty, guarantee and evidence of an impartial expert and legal advisor who does not have a disability.

The role of a notary in helping to realize legal certainty for the community is more of a prevention of legal problems which is carried out by issuing an authentic deed. The authentic deed he made regarding the legal status, rights and obligations of a person in law serves as perfect evidence. ${ }^{4}$

The role of a notary in making a deed is limited, not all authentic deeds can be made by a notary. Deeds relating to legal actions regarding land can only be made by the official making the land deed or abbreviated as PPAT ${ }^{5}$.

An authentic deed made by a notary or PPAT is sometimes disputed by one party or by another party because it is considered detrimental to their interests or violates their rights. Some of the things that are often disputed include denying

\footnotetext{
${ }^{1}$ Asshiddiqie, Jimly. (2006). Konstitusi dan Konstitusionalisme Indonesia. (Cetakan Kedua) Jakarta: Konstitusi Press. p. 69.

${ }^{2}$ Is, Is, Muhamad Sadi. (2015). Pengantar IImu Hukum. (1st printing) Jakarta: Prenadamedia Group. p. 177.

3Jalal, Abdul, Suwitno \& Wahyuningsih, Sri Indah, "Keterlibatan Pejabat Notaris Terhadap Perbuatan Melawan Hukum Dan Turut Serta Melakukan Tindak Kejahatan Dalam Pemalsuan Dokumen", dalam Jurnal Akta, Volume 5 No. 1, accessed on 26 July 2021 at 06.56 WIB

${ }^{4}$ Sjaifurrachman, (2011), Aspek Pertanggungjawaban Notaris Dalam Pembuatan Akta, (First Edition). Bandung: Mandar Maju. p. 7.

${ }^{5}$ Ong Argo Victoria, Ade Riusma Ariyana, Devina Arifani. (2020). Code of Ethics and Position of Notary in Indonesia. Sultan Agung Notary Law Review 2 (4), 397-407, http://lppmunissula.com/jurnal.unissula.ac.id/index.php/SANLaR/article/view/13536
} 
the contents of the deed, signature or presence of parties before a notary or PPAT, and sometimes there are allegations of false information in an authentic deed. ${ }^{6}$

The breadth of authority possessed by a notary and PPAT sometimes leads to abuse of authority by taking actions that can harm the client or other people. For example, the falsification of the signature of a land title certificate by a PPAT that occurred in Sambas Regency, West Kalimantan Province. ${ }^{7} \mathrm{~A}$ similar case has also occurred, but was carried out by a notary. In fact, what was forged was not only a signature, but a deed of sale and purchase agreement. Making the deed is a collaboration between a notary and other parties with the aim of obtaining ownership of a shophouse. ${ }^{8}$

Based on this case, it is necessary enforcement of discipline and law enforcement in the professional environment. One of efforts to Minimizing the occurrence of violations committed by notaries and PPATs is to supervise and develop the two legal professions.

Supervision of notaries is carried out by the Ministry of Law and Human Rights of the Republic of Indonesia. ${ }^{9}$ The implementation of supervision by the minister is carried out by establishing a Supervisory Council. Meanwhile, supervision of PPAT is carried out by the Ministry of Agrarian Affairs and Spatial Planning. ${ }^{10}$ The implementation of supervision is also carried out by establishing an institution called the PPAT Supervisory and Supervisory Council.

\section{Research Methods}

The approach method used in this research is the juridical-normative approach. As for what is meant by a juridical approach, it is a method used in a study that

\footnotetext{
${ }^{6}$ Sholikhah, Entin \& Hafidz, Jawade, "Perlindungan Hukum Terhadap Jabatan Notaris Yang Diduga Melakukan Malpraktek Dalam Proses Pembuatan Akta Otentik", dalam Jurnal Akta Volume 4

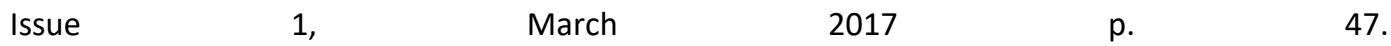
URLs:http://jurnal.unissula.ac.id/index.php/akta/article/view/1570/1204 accessed on July 25, 2021 at 21:37.

7"Palsukan Tanda Tangan, Oknum Notaris Divonis 5 Bulan Penjara”, https://pontianak.tribunnews.com/2015/11/13/palsukan-tanda-tangan-oknum-notaris-divonis-5bulan-penjara accessed on January 9, 2021, at 06.23.

8 Prio, B Sadono ."Kembali Berulah, Notaris Ubah Akta Perjanjian Pengikatan Jual Beli Ruko", https://www.suarakarya.id/detail/101985/Kembali-Berulah-Notaris-Ubah-Akta-Perjanjian-

Pengikatan-Jual-Beli-Ruko accessed on January 10, 2021, at 20.36.

${ }^{9}$ Article 67 of Act No. 2 of 2014 concerning Amendments to Act No. 30 of 2004 concerning the Position of Notary

10 Article 33 Government Regulation Number 24 of 2016 concerning Amendments to Government Regulation Number 37 of 1998 concerning Position Regulations for Land Deed Maker Officials
} 
uses principles and laws and regulations to review, view and analyze problems that exist in society. The juridical approach is used, among others, to analyze various legal theories and laws and regulations, related to the comparison of supervision of notaries and PPAT. While the normative research method is a legal research conducted by examining literature review materials. ${ }^{11}$

\section{Results and Discussion}

\subsection{State Power Theory}

The theory of state power that has been put forward by Montesqiu explains that state power is divided into 3 (three) namely executive power, legislative power and judicial power. ${ }^{12}$

Notaries and PPATs in carrying out their duties and authorities, namely making perfect legal evidence, are considered to have exercised legislative power as well as judicial power. However, the implementation is not general and comprehensive.

As executor of legislative power, notaries and PPATs have the authority to make authentic deeds as stipulated in Article 15 paragraph 1 UUJN and Article 2 paragraph 1 PP PPAT. The authentic deed is legally binding on the parties like the law for the parties and may contain sanctions if any party is in default.

The judicial power attached to the notary and the PPAT lies in the obligation of the notary and the PPAT to properly keep all the minutes of the deed that he has made as stated in Article 16 paragraph 1 points b, c, d, f, g, i, j, k UUJN and Article 25, 26 \& 29 PP PPAT. This obligation indirectly helps law enforcement, because the notary and PPAT keep evidence that can be used as a reference in the trial.

Such authority of a notary and PPAT should be accompanied by supervision, this is in line with the purpose of the division of state power, namely the creation of checks and balances. The principle of checks and balances serves to limit the authority or power so as to minimize the abuse of authority and facilitate the implementation of supervision. ${ }^{13}$

\subsection{Supervision Theory}

\footnotetext{
${ }^{11}$ Salim.HS dan Erlies Septiana Nurbani, Penerapan Teori Hukum Pada Penelitian Tesis Dan Disertasi, RajaGrafindo Persada, Depok, 2013, p. 12

${ }^{12} \mathrm{Huda}$, Ni'matul. (2015). Ilmu Negara. Jakarta: Rajawali Pers. p. 73.

${ }^{13}$ Gaffar, Afan. (2006). Politik Indonesia: Transisi Menuju Demokrasi. Yogyakarta: Pustaka Pelajar. p. 89.
} 
The author in this study refers to the supervisory theory proposed by Maringan Masry Simbolon and Husaini Usman. According to Maringan Masry Simbolon, there are several types of supervision, namely: ${ }^{14}$

a. supervision from within the organization carried out by an institution formed by the organization itself;

b. supervision from outside the organization, namely supervision carried out by institutions from outside the organization;

c. preventive supervision, namely supervision carried out before a plan is implemented; and

d. Repressive supervision is supervision carried out after the implementation of an activity.

Another opinion was expressed by Husaini Usman who stated that there are 2 (two) types of supervision, namely:

a. inherent supervision, namely supervision carried out by superiors who have power and can act freely from conflicts of interest;

b. Functional supervision is a supervisory effort carried out by an institution specifically appointed to supervise freely the object of supervision.

Comparison of supervision of notaries and PPAT is focused on four things, namely the form of supervision, type of supervision, supervisory mechanism and authority \& scope of supervision

\section{Supervision Form}

Notary supervisory agencies and PPAT have differences in terms of interpreting and providing limits on supervision based on their respective legal bases.

a. Notary Supervisory Board

The Notary Supervisory Council defines supervision as an activity that is preventive and curative in nature, including coaching activities carried out by the Supervisory Council of Notaries. ${ }^{15}$ Further explanations regarding these three things were not explained by the MPN Ministerial Decree.

The three supervisions have been mentioned by Maringan Masry Simbolon, except for coaching, so that coaching is an extension of the meaning of supervision according to UUJN. Meanwhile, curative supervision has the same meaning as repressive supervision, which is both carried out after the implementation of an activity.

\footnotetext{
${ }^{14}$ Simbolon, Maringan Masry. (2004). Dasar-Dasar Administrasi dan Manajemen. Jakarta: Ghalia Indonesia. p. 62.

${ }^{15}$ See Article 1 point 6 of the Regulation of the Minister of Law and Human Rights of the Republic of Indonesia Number 16 of 2021 concerning Organizational Structure and Work Procedures, Procedures for Appointment and Dismissal, and Budget of the Notary Supervisory Board
} 


\section{b. Honorary Council}

INI Articles of Association and INI Code of Ethics do not explain the form of supervision carried out by the Honorary Council or abbreviated as DK. So that the form of supervision carried out by the DK can be concluded from the duties of the DK itself.

Based on Article 12 paragraph (2) of THIS Articles of Association which mentions several tasks of the DK, it can be understood that the supervisory form of the DK is more focused on repressive supervision.

c. PPAT Supervisory and Trustee Council

The PPAT Supervisory and Trustee Council or abbreviated as MPP PPAT supervises PPAT through preventive and repressive administrative activities with the aim that PPATs carry out their positions in accordance with the provisions of the legislation. ${ }^{16}$ The form of preventive and repressive supervision carried out by MPP PPAT can be seen in the provisions of Article 8 of the PPAT Supervision Regulation which states that supervision of PPAT can be in the form of:

1) supervision of the implementation of PPAT positions; and

2) enforcement of the rule of law in accordance with the provisions of the legislation in the field of PPAT.

d. Honorary Council of the Association

Supervision of PPAT is not only carried out by the Supervisory Council and PPAT Trustees, it is also carried out by the Association of Land Deed Maker Officials through the formation of the Association's Honorary Council.

The form of supervision carried out by MKP is not further explained by the PPAT Code of Ethics and AD IPPAT, but if you examine the PPAT Code of Ethics thoroughly, according to the author, MKP supervision is more inclined to a repressive form of supervision. MKP's repressive supervision can be seen in the provisions of Articles 9 to 12 of the PPAT Code of Ethics which regulates the mechanism for examining and imposing sanctions at the first level by the Regional Honorary Council and at the appeal level by the Central Honorary Council.

\section{Monitoring Type}

The independent nature of a supervisory agency is also determined by the type of supervision it has. If the supervisory agency has a strong position and is independent in nature, then the supervisory agency has a wider range of motion in carrying out supervision of notaries and PPATs.

a. Supervisory Board

Based on the opinion of Maringan Masry Simbolon, the supervision carried out by the Supervisory Council includes supervision from outside the organization. This is because the Supervisory Council was formed by the Menkumham based on Article 67 paragraph (2) of the UUJN so it was not formed by a notary

\footnotetext{
${ }^{16}$ Article 1 point 3 Regulation of the Minister of Agrarian Affairs and Spatial Planning/Head of the National Land Agency of the Republic of Indonesia Number 2 of 2018 concerning Guidance and Supervision of Land Deed Maker Officials
} 
organization. Meanwhile, according to Husaini Usman, MPN supervision is included in the type of functional supervision, because it is carried out by an institution specifically appointed to carry out independent supervision.

b. Honorary Council

As an organizational tool, the supervision carried out by the DK in the opinion of Maringan Masry Simbolon is supervision from within the organization, because it is formed and acts on behalf of the organization. Meanwhile, according to Husaini Usman, the supervision of the DK in general includes mixed supervision between functional supervision and inherent supervision, because the DK is basically a separate institution that is free from intervention, but the implementation of its supervision is not completely independent and independent because its supervision is carried out together with INI management.

c. PPAT Supervisory and Trustee Council

The formation of the MPP PPAT conducted by the Minister of Agrarian Affairs and Spatial Planning shows that this supervision includes supervision from outside the organization. Meanwhile, according to Husaini Usman, MPP PPAT is an institution appointed to supervise so that it is included in the type of functional supervision, but in carrying out its supervision of PPAT, MPP PPAT does not act alone but together with the Head of the BPN Regional Office or the Head of the Land Office so that the type of supervision is not fully functional supervision. .

d. Honorary Council of the Association

The type of supervision carried out by MKP includes supervision from within the organization, because it was formed and authorized by the IPPAT Articles of Association and the PPAT Code of Ethics. Meanwhile, according to Husaini Usman, MKP supervision carried out together with IPPAT shows that the type of supervision is a mixture of inherent supervision and functional supervision.

\section{Monitoring Mechanism}

Each supervisory agency has a supervisory mechanism that has been regulated respectively in the laws and regulations of the association.

a. Supervisory Board

The implementation of supervision by the MPN regarding preventive, curative and coaching supervision based on the provisions of Articles 27 to 35 of the MPN Ministerial Regulation is fully carried out by the MPN without any intervention or intervention from either the Menkumham or INI. This freedom to carry out supervision is what distinguishes MPN from other supervisory institutions.

b. Honorary Council

Article 7 of the Notary Code of Ethics states that supervision over the implementation of the code of ethics is carried out by INI Management and the Honorary Council at all levels. On the one hand, the DK is an organizational tool as stated in Article 10 of THIS AD and the DK represents INI in terms of guidance, supervision and sanctions as referred to in Article 12 paragraph (1) of THIS AD. If 
the DK represents INI in terms of supervision, then according to the author, the implementation of the notary code of ethics supervision should be carried out by the DK itself without the participation of INI's management.

c. PPAT Supervisory and Trustee Council

The supervisory mechanism implemented by the PPAT MPP has been regulated in Article 10 of the PPAT Supervision Regulation which states that the supervision is carried out by examination at the PPAT office or other supervisory methods. Supervision is basically carried out by the Head of the BPN Regional Office or the Head of the Land Office periodically and at least 1 (one) time in 1 (one) year. Unfortunately the role of MPP PPAT in the supervisory mechanism is limited to assisting and not as the main implementer.

d. Honorary Council of the Association

Article 7 points $a$ and $b$ of the PPAT Code of Ethics state that at the first level the supervision over the implementation of the code of ethics is carried out by the PPAT Regional Management and the Regional Honorary Council together with the Regional Management and all members of the IPPAT association, then at the last level carried out by the IPPAT Central Management and Central Honorary Council. These provisions indicate that the supervisory mechanism carried out by the MKP has similarities with the supervisory mechanism of the DK, which is carried out together with professional organizations.

\section{Authority and Scope of Supervision}

The supervisory agency that supervises notaries and PPATs has different authorities and different scopes of supervision.

\section{a. Supervisory Board}

Article 27 of the MPN Ministerial Regulation has regulated several types of MPN authority which are divided into 4 (four) namely:

1) fostering and supervising Notaries as well as conducting examinations of alleged violations of the behavior and implementation of the Notary's position;

2) administration which does not require the approval of the Supervisory Board meeting;

3) administration which requires the approval of the Supervisory Board meeting; and

4) routine checks.

The supervision carried out by the MPN as previously explained in the form of preventive supervision, curative supervision and coaching. The implementation of the three types of supervision has been summarized by the author as follows:

1) Preventive Surveillance 
The preventive supervision carried out by the MPN in Article 70 point $b$ of the UUJN and Article 30 point $b$ of the MPN Ministerial Regulation states that there are routine inspections carried out by the MPD 1 (one) time a year or at any time deemed necessary.

\section{2) Curative Supervision}

The implementation of curative supervision by the Supervisory Council is based on several articles in the MPN Ministerial Regulation including:

a) authorized to receive reports from the public regarding alleged violations of the code of ethics and violations of statutory provisions;

b) summon the reported notary public for examination;

c) holding a hearing to examine the notary regarding allegations of violations of the code of ethics and violations of statutory provisions;

d) MPW has the authority to examine and decide on the results of the MPD examination and is authorized to give sanctions in the form of verbal and written warnings; and

e) MPP has the authority to give sanctions in the form of temporary dismissal or propose sanctions for respectful or dishonorable dismissal to the Menkumham.

3) coaching

The MPN Ministerial Regulation does not explain in more detail how the form of guidance carried out by the MPN both in terms of authority and obligations, so that the implementation of this guidance is fully returned to each Supervisory Council.

The Notary Supervisory Council is also given supervisory authority with a scope that includes the behavior of a notary and the implementation of notary positions as referred to in Article 67 paragraph (5) of the UUJN.

b. Honorary Council

The Honorary Council is one of the tools of the Indonesian Notary Association. THIS Articles of Association, THIS Bylaws and the Code of Ethics of the three Notaries do not explicitly mention the authority of the DK, but only mentions the tasks assigned to the DK which are contained in Article 12 paragraph (2) of THIS Articles of Association:

1) conduct guidance, supervision, guidance for members in enforcing and upholding the Notary Code of Ethics;

2) examine and make decisions on alleged violations of the provisions of the Notary Code of Ethics; 
3) provide suggestions and opinions to the Supervisory Council and/or the Notary Honorary Council on alleged violations of the Notary Code of Ethics and the position of a Notary;

4) coordinate, communicate, and relate directly to members and parties related to the implementation and enforcement of the Notary Code of Ethics;

5) make regulations in the context of enforcing the Notary Code of Ethics together with the Central Executive.

In addition to THIS Articles of Association, the duties of the DK have also been mentioned in Article 58 paragraph (6) and 59 paragraph (6) of this Bylaws which states that the DKW and DKD have the duty and obligation to provide guidance and supervise the implementation and compliance of the notary code of ethics. by INI members in their respective territories. The scope or object of supervision carried out by the DK is limited to the notary code of ethics.

\section{c. PPAT Supervisory and Trustee Council}

The authority of the PPAT MPP is not specifically regulated in the PPAT Supervision Regulation, so a thorough review of the PPAT Supervision Regulation must be carried out. PPAT supervision includes 2 (two) things, namely:

\section{1) Supervision of the Implementation of PPAT Positions}

Supervision of the implementation of PPAT positions based on Article 10 paragraph (2) of the PPAT Supervision Regulation is carried out by the Head of the BPN Regional Office and the Head of the Land Office. The implementation of the supervision based on Article 10 paragraph (4) of the Regulation of PPAT Supervision can be assisted by MPP PPAT and carried out by inspection to the PPAT office.

2) Law enforcement in accordance with the provisions of the legislation in the field of PPAT.

Supervision in the form of enforcement of the rule of law is carried out if there are findings from the Ministry regarding violations of the implementation of PPAT's positions or there are complaints of alleged violations committed by PPAT.

If a complaint has been received by the Ministry, BPN Regional Office, Land Office, MPP PPAT or IPPAT, the complaint is forwarded to the MPPD. 
Based on the description above, it is concluded that the authority of the MPP PPAT is more emphasized on the enforcement of the rule of law, namely the mechanism for examining alleged violations of PPAT.

The scope of supervision carried out by MPP PPAT includes violations of statutory provisions and violations of the PPAT code of ethics.

3) Honorary Council of the Association

The MKP's authority has been contained in AD IPPAT and the PPAT Code of Ethics which states that MKP is obliged to carry out the rules for enforcing the code of ethics that are made and ratified by Congress. The definition of MKP contained in Article 1 point 8 of the PPAT Code of Ethics also mentions several tasks and/or authorities of MKP, namely conducting guidance, supervision, control and improvement and summoning, examining and imposing decisions in the form of sanctions or penalties.

The MKP's authority is also contained in Article 7 of the PPAT Code of Ethics, namely the supervisory authority carried out together with IPPAT elements. MKP is an independent and free institution so that in carrying out its duties as much as possible it avoids IPPAT intervention.

Therefore, according to the author, changes must be made to the rules of the PPAT code of ethics, either by adding explanations or changing articles so as not to cause multiple interpretations of the provisions of the PPAT code of ethics.

\section{Conclusion}

Notaries and PPATs are public officials who are authorized to make authentic deeds based on statutory regulations, therefore notaries and PPATs are considered to be exercising part of the state's power in the realm of civil law by making perfect evidence indicating the occurrence of a legal event. Based on the theory of state power put forward by Montesqiu, notaries and PPAT exercise 2 (two) state powers at once, namely legislative power through the making of authentic deeds and judicial power through the storage of authentic deeds and other protocols. As executor of state power, the notary and PPAT must always be supervised with the aim of creating conditions of checks and balances. Based on the supervisory theory put forward by Maringan Masry Simbolon and Husaini Usman. 


\section{References}

Journals:

[1] Abdul Jalal, Suwitno \& Sri Indah Wahyuningsih, "Keterlibatan Pejabat Notaris Terhadap Perbuatan Melawan Hukum Dan Turut Serta Melakukan Tindak Kejahatan Dalam Pemalsuan Dokumen", in Jurnal Akta, Volume 5 No. 1, March 2018, url: http://jurnal.unissula.ac.id/index.php/akta/article/view/2551/1912

[2] Entin Sholikhah \& Jawade Hafidz, "Perlindungan Hukum Terhadap Jabatan Notaris Yang Diduga Melakukan Malpraktek Dalam Proses Pembuatan Akta Otentik", in Jurnal Akta Volume 4 Issue 1, March 2017, url: http://jurnal.unissula.ac.id/index.php/akta/article/view/1570/1204.

[3] Ong Argo Victoria, Ade Riusma Ariyana, Devina Arifani. (2020). Code of Ethics and Position of Notary in Indonesia. Sultan Agung Notary Law $\begin{array}{lllll}\text { Review } & 2 & \text { (4), 397-407, } \quad \text { http://lppm- }\end{array}$ unissula.com/jurnal.unissula.ac.id/index.php/SANLaR/article/view/13536

Books:

[1] Affan Gaffar, (2006), Politik Indonesia: Transisi Menuju Demokrasi. Yogyakarta: Pustaka Pelajar.

[2] HS Salim dan Erlies Septiana Nurbani, (2013), Penerapan Teori Hukum Pada Penelitian Tesis Dan Disertasi, Depok: RajaGrafindo Persada.

[3] Jimly Asshiddiqie, (2006), Konstitusi dan Konstitusionalisme Indonesia. (Second Edition), Jakarta: Konstitusi Press.

[4] Maringan Masry Simbolon. (2004). Dasar-Dasar Administrasi dan Manajemen. Jakarta: Ghalia Indonesia.

[5] Muhamad Sadi Is, (2015), Pengantar Ilmu Hukum. (First Edition) Jakarta: Prenadamedia Group.

[6] Ni'matul Huda, (2015), Ilmu Negara. Jakarta: Rajawali Pers.

[7] Sjaifurrachman, (2011), Aspek Pertanggungjawaban Notaris Dalam Pembuatan Akta, (First Edition). Bandung: Mandar Maju.

Regulations:

[1] Act No. 2 of 2014 concerning Amendments to Act No. 30 of 2004 concerning the Position of Notary

[2] Government Regulation Number 24 of 2016 concerning Amendments to Government Regulation Number 37 of 1998 concerning the Regulation of the Position of Land Deed Officials

[3] Regulation of the Minister of Law and Human Rights of the Republic of Indonesia Number 16 of 2021 concerning Organizational Structure and 
Work Procedures, Procedures for Appointment and Dismissal, and Budget of the Notary Supervisory Council

[4] Regulation of the Minister of Agrarian and Spatial Planning/Head of the National Land Agency of the Republic of Indonesia Number 2 of 2018 concerning Guidance and Supervision of Land Deed Maker Officials

Internet:

[1] B Sadono Prio, "Kembali Berulah, Notaris Ubah Akta Perjanjian Pengikatan Jual Beli Ruko", https://www.suarakarya.id/detail/101985/Kembali-Berulah-NotarisUbah-Akta-Perjanjian-Pengikatan-Jual-Beli-Ruko.

[2] "Palsukan Tanda Tangan, Oknum Notaris Divonis 5 Bulan Penjara", https://pontianak.tribunnews.com/2015/11/13/palsukan-tanda-tanganoknum-notaris-divonis-5-bulan-penjara. 